\title{
Judicial Activism in Judge's Verdict to Law Enforcement of Environment
}

\author{
Aju Putrijanti* \\ Faculty of Law, Diponegoro University, Semarang
}

\begin{abstract}
Law enforcement to protect the environment as lay in Act Number 32 Year 2009 of Protection and Management of Environment, can be make from administrative, penal and private law. Government that includes legislative, executive and judicative has role and responsibility to perform welfare for citizen. The administrative lawsuit goes to Administrative Court, follows the Act Number 5 Year 1986 of Administrative Court for procedural process. This research based on normative legal research, which is descriptive analysis. Also using conceptual and statute approach, and research data used are literature and secondary data. The good understanding of principle of good environment, become important for judge and government to do their duties to protect the environment. Judge has an important role in law enforcement due to protection of environment, by using judicial activism. Through judge's verdict, judge has to conceive wisely the importance of environment and the principle of good environment governance. Government should be based on environment ethic as a guidance to make, prepare the regulations, permissions due to protection of environment. Antroposentris and biosentris approach might be used to prepare the green regulations and green permissions.
\end{abstract}

Keywords: judicial activism, judge verdict, law enforcement

\section{Introduction}

In the Constitution of Republic of Indonesia 1945, Article Number 28H stated that everyone has rights of good and health environment. In the fast changing of nations, politics and economics there are developments which sacrifice, degrading the environment and dangered the life for human being. As state of law, all the government's affairs followed theory of Montesqiue, are divided into executive, legislative and judicative. Each function of government's affairs has an important role to protect the environment and perform the welfare. There are two types of governance, first state as guardian where governance has less power but required to create and give situation in order to realize the welfare being. Second is welfare state, request the activism of governance to increase the

\footnotetext{
* Corresponding author: ajuputrijanti@lecturer.undip.ac.id
} 
welfare being[1]. As welfare state, the government's interventions is important to control, regulates all sectors related to citizen, such as providing for housing, healthcare, education, etc.

In the environment's management, principle of state responsibility is important, besides thirteen principles as stated in Article number 2 Act Number 32 Year 2009 of Protection and Management of Environment, it should be followed by government and everyone. The management of environment, needs cooperation from all sector, whether government, legal entity, private or groups, as stakeholder. The use of environment with less conscientious, will absolutely damage our life and habitat. The judiciary functions under Supreme Court has authority to law enforcement and justice based on Pancasila and Constitution 1945. Administrative Court (herein after is Court) is specialized court under Supreme Court with competence to investigate, decide and settle administrative disputes, based on Article Number 47 Act No 5 Year 1986 of Administrative Court and its amendments.

Stated by Carolyn Abbot that law enforcement in environmental law by supervision and administrative sanctions have benefit than law enforcement by penal law and environment disputes by private law. The benefits are, first is the process is fast and does not need many sources, second is the power of administrative sanctions not given by court but the special supervisor who has the related and competence of science of defendant[2]. Previous research about administrative sanctions in law enforcement which had been done by Grahat Nugraha and Andri Gunawan Wibisana has find out that there is no common understanding among the regulations related to environment. This is an important matter, since government has an authority to make regulations based on society oriented.

In Article Number 93 Act Number 32 Year 2009 of Protection and Management of Environment, it is possible to put lawsuit to Court, and the procedure follows the Act Number 5 Year 1986 of Administrative Court and its amendments. It means that, if there is an administrative lawsuit then it will use the regulations of administrative procedural. This article will focus on the judicial activism by judge when they make the consideration, in order to protect the environment. The judicial activism is important, because judge has to understand quite well about the importance of environment, not only as stated in the regulations. The execution of judge's verdict, also obstruct the justice and environment protection.

That being said, the execution of judge's verdict in Administrative Court is always troubled. As stated by Supandi, that after fourteen years the Court had not fulfilled the citizen's expectation yet. Emphasized by Ismail Rumadan, that the weakness of execution system in Court also contributes, the diffulties of judge's verdict execution, because of some reasons. First, the floating execution system, second is the amount of forced money, third is the execution relates with regional autonomy will arise the new problem[3]. This is classical problems, and there is still no way out yet to solve. Law enforcement in environment administrative lawsuit lays on two important points as this become the problems. First, how is judge's role to law enforcement to protect environment, second, how is the role of government to built an envirionmental governance?

The aims of this research is to find out the judge's role by using judicial activism in law enforcement, and to know the role of government to built an environmental governance so the output will be green regulations and green permissions. This research uses normative legal research, and use conceptual and statute approach, to analyze the datas. Research data is use literature and secondary datas. The statutes are regulations relates with the problems, i.e Act Number 5 Year 1986 of Administrative Court and its amendments, Act Number 32 Year 2009 of Protection and Management of Environment, Act Number 48 Year 2009 of Judicial Power. 


\subsection{Discussions}

\subsubsection{The Role of Administrative Court}

Act Number 32 Year 2009 of Protection and Management of Environment regulates 3 (three) types of law enforcement to protect the environment, i.e: civil lawsuit, criminal prosecution both goes to general court, and administrative lawsuit goes to Court. Satjipto Rahardjo said, law enforcement means an effort to actualized concepts or ideas became concrete. Sjachran Basah explained that the concrete law enforcement is practically implementation of regulations, while Moestadji said law enforcement as an effort to implement the sanction from administrative, private and penal law[4]. Law enforcement in environmental law as an effort to implement the regulations of environment to achieve the goals and considering principles of good environment governance, environmental rule of law.

Refer to system of law by Lawrence Friedman, there are legal substance, legal structure and legal culture which has great influence in law enforcement. As stated by Siti Sundari Rangkuti, in future the empowerment of Court must be improved in order to stop environment pollution as a result of environment's permission given by public officer [5] . The cancellation of permission by Court is one effort of law enforcement, besides other effort to protect the environment and to prevent pollution. Judge in Court has important point as structure in law enforcement. Before judge allow to investigate the environment's lawsuit, they should have environment's certificate, as this is a requirement. Besides normative requirement, the conceive of environment not only as stated in the regulations, but the values of environment also important. Moreover, to conceive and appreciate values of environment, judge should implement and develop judicial activism, in order to give a substance and normative justice in the same time. Judge should be able to dig and find the law to protect the environment, this is a duty of judge as stated in article number 5 in Act Number 48 Year 2009 of Judiciary Power. The judicial activism is a tool for judge to fulfill the duty to give administrative and substantive justice.

Eventhough the requirements of environment lawsuit refer to Act Number 5 Year 1986 of Administrative Court and its amendments, there are still some differences should be noticed. Plaintiff should fulfill this requirements, while it will takes several times to check, and actually this long requirements takes more times than general administrative lawsuit. This requirements should be more shorter than before, there should be a new and simplified process to get substantial environment justice. Beside the regulations, Judge also has an important role in law enforcement to protect the environment, by using judicial activism. Judicial activism have been used in judge's verdict in order to actualized the protection of human rights of people who has litigate. The judge's consideration in implementation of judge verdict may be vary for some cases, this can be based on political, society development rather than the existing law.

The landmark decision of judicial activism, in the case Brown v Board Education 1954 of elimination of racial segregation in America, also case Roe v Wade 1973, in both cases judges cancel the previous judge verdict and precedent by using the doctrine separate but equal[6]. The implementation of judicial activism in democracy state mainly aimed to the fundamental rights which is stated in Constitution. The practice of judicial activism was developed in country using Anglo Saxon system of law. For example, India, judicial activism has been used to safe the indigent, and provide legal remedies for those who needs and deprived against law. In United States, it has been used to protect the minorities of their rights and interests. The difference is in China, judicial activism should be viewed as a different and unique form in the context of law milieu. Since they have different politic and judiciary system, that is why they have different style of judicial activism[7]. The 
implementation of judicial activism is adjust to politic, society, law, and democratic approach in each country.

One of the form of judicial activism, when Judge also considering the duty of government officer to protect the Region Ecosystem of Leuser as stated in the regulation[8]. Judge not only examine the procedural, authority and substance of dispute object, but also tried to dig more deeper about the meaning of environment. Judge should have a wide knowledge, view of the importance of environment, it means not only the things listed in the regulations, especially about the principle of good environment. The deep understanding and knowledge of environment, will help judge to contribute the law enforcement to protect the environment. Judge can not only give procedural justice, but substantial justice also important to give justice to whomsoever needs.

When judge verdict neglects the role of society as stated in Article number 70 of Act Number 32 Year 2009 of Protection and Management of Environment, it is an incorrect consideration and injured the justice in the society perception. When they get all the risks and consequences, it is important to have a wise, good information of the interests from society who lives nearby, and their struggle to keep the environment healthy and clean. Some factors which influenced the law enforcement are neutral, but the positive and negative impact lay on substance, first, is the regulations. Second, the legislative and law enforcement, third, the facility that support law enforcement, fourth, the society where the law is enforced, fifth, culture of society as lived in the society[9]. The legislative is made the regulations to be implemented by society, and if there is any damage occur, the society can make the lawsuit to Court or report to officer. It is a duty of judge, to have a wideviews and understanding about the principle of good environment and the relations between environment and universe.

\subsubsection{Environmental Governance}

Before we discuss about environmental governance, it is better to understand the meaning of environmental law from experts. Scott Fulton said " environmental law is expression of normative expectations pertaining environment" in his presentation at "1st Asia Pacific International Colloquium on Environmental Rule of Law : Defining a New Future for Environmental Justice, Governance and Law"[10]. In the frame of governance, to make regulations should concern of principle of good environment, which develop from principle of good governance.

The implementation of principle of good environment, should based on environment ethic, while the ethic as a norm became a fundamental based to make regulations, permissions due to protect the environment. Environment ethic emphasized the relations between live in the universe, which has a broad understanding and guidance of how to behave to protect and respect the universe. Environment ethic should be inspired by government while making and preparing the regulaions, permissions to use the environment. Antroposentris and biosentris approach might be use to produce a green regulation so does green permissions.

The Act Number 32 Year 2009 of Protection and Management of Environment use antroposentris instead of biosentris, when actually biosentris have more relations to environment than antroposentris. In making regulations, the existing authority should considering the respect to universe beyond the limit regulations, common sense and behaviour. As a human being it is our responsibility to protect and control the damage and pollution. This responsibility not limited as a government officer only, but as a part of universe. The misuse of antroposentris approach, also contribute in false permission given. When the development should be implemented, not by itself put the society needs as superior, and neglect the environment conservation. Antroposentris approach is not a 
mistake, but the misuse by some people will make it unappropriated approach, and damage the environment and universe[11].

Regulations of administrative sanction in environment's infringement, shows the uncertainty of formulation regulations. Faure and Visser as quoted by Grahat Nugraha, stated that administrative sanction can be difficult because of first, there is no conviction or non - monetary sanction, second, put the persuasive obedience rather than prevention, and three, administrative sanction can be supported by penal law to strengthening the law enforcement. His research, showed there are no legal certainty in administrative law enforcement, such as norm, procedure and criteria. The uncertainty of administrative violation to define the damage environment which can charged with administrative sanction, since there are no definite meaning in some regulations, about forestry, plantation, and mining[12]. The uncertainty from regulations will give difficult law enforcement from administrative, penal and private law, because there should be a definite and clear formulation of regulations. The norm of ethic environment as a basic to build the procedure and criteria of sanctions.

According to Andri Gunawan Wibisana, there are two conceptual mistakes about administrative sanctions in Act Number 32 Year 2009 of Protection and Management of Environment and governments regulations. First, the violation of environmental law only given by command sanction to do something, without any possibility to forced by government upon the cost and risk from violator. Second, the violation of environmental law will not get penalty as administrative sanction[13]. The difference of administrative sanction to penal or private sanction that there is no need of judiciary command for implementation. Administration sanction will be given by the government officer without judge verdict or command or order from administrative court. The uncertainty concept of law regulation about administrative sanctions, will give difficulties for law enforcement so does the protection and management of environment.

\subsection{Conclusion}

Law enforcement in administrative law to protect the environment, can be done through judge verdict. Judge expected to investigate, consider the environment lawsuit by using judicial activism, meaning that there should be a wideviews of principles of good environment, the importance of environment and the environment of law. While this combine with normative requirements of lawsuit based on environment's lawsuit.

Governance has to use an ethic of environment, to prepare regulations and permission to build the environment. By using antroposentris and biosentris approaches, the environment ethic as fundamental principle to protect and management the environment. Environment ethic is important for government to obey and implement the judge's verdict.

\section{References}

[1] I. G. Ayu and A. Hadi, "Pertanggungjawaban Pejabat Pemerintahan Dalam Tindakan Diskresi Pasca Berlakunya Undang-undang No. 30 Tahun 2014 Tentang Adminisitrasi Pemerintahan," Kertha Patrika, vol. 39, no. 1, pp. 33-46, (2017).

[2] A'an Efendi, "Pengelolaan Lingkungan," in Hukum Pengelolaan Lingkungan, Bambang Sarwiji, Ed. Jakarta: Indeks Jakarta, (2018), pp. 23-85.

[3] Ismail Rumadan, "Problematika eksekusi putusan pengadilan tata usaha negara," $J$. Huk. dan Peradil., vol. 1, no. 3, pp. 435-462, (2012).

[4] A. Mubin, "Hak Gugat Pemerintah untuk Penggantian Kerugian dan Pemulihan Lingkungan Dalam Sengketa Lingkungan Hidup," Nagari Law Rev., vol. 1, no. October, pp. 1-15, (2017). 
[5] M. T. W. dan Malik, "K onteks P olitik H ukum D i B alik P ercepatan P enetapan H utan A dat: C atatan K e A rah T ransisi 2019," J. Huk. Lingkung. Indones., vol. 4, no. 2, pp. 25-46, (2018).

[6] A. Latipulhayat, "Mendudukan Kembali Judicial Activism dan Judicial Restraint Dalam Kerangka Demokrasi," Padjajaran J. Ilmu Huk., vol. 4, no. 3, pp. i-iv, (2017).

[7] I. Amarini, "IMPLEMENTATION OF JUDICIAL ACTIVISM IN JUDGE' S DECISION," J. Huk. dan Peradil., vol. 8, no. 1, pp. 21-38, (2019).

[8] A. A. Nugroho, "Analisis Putusan PTUN NO. 7/G/LH/2019/PTUN.BNA antara Walhi Melawan Gubernur Aceh atas Penerbitan Izin Pinjam Pakai Kawasan Hutan untuk Pembangunan PLTA Tampur," J. Huk. Lingkung. Indones., vol. 6, no. 1, pp. 126-144, (2019).

[9] A. A. M. Yunus Wahid, Naswar Bohari, "Penegakan Hukum Lingkungan di Sektor Kehutanan (Studi Kawasan Hutan Lindung di Kabupaten Sinjai, Sulawesi Selatan)," Hasanuddin Law Rev., vol. 1, no. 1, pp. 61-73, (2015).

[10] Takdir Rahmadi, "Penegakan Hukum Lingkungan Dan Penyeleseaian Sengketa Lingkungan," in Hukum Lingkungan di Indonesia, Jakarta: PT RajaGrafindo Persana, (2011), pp. 199-289.

[11] R. Sembiring, "Tinjauan Etis atas Fenomena Relativisme Hukum dalam Kasus Pabrik Semen di Rembang," J. Huk. Lingkung. Indones., vol. 5, no. 2, pp. 208-233, (2019).

[12] Grahat Nagara, "P erkembangan Sanksi A dministratif Dalam P enguatan Perlindungan Lingkungan T erkait Eksploitasi Sumber D aya Alam ( Studi K asus : S ektor P erkebunan, P ertambangan, dan K ehutanan )," J. Huk. Lingkung. Indones., vol. 3, no. 2, pp. 19-44, (2017).

[13] Andri Gunawan Wibisana, "Tentang Ekor yang Tak Lagi Beracun: Kritik Konseptual atas Sanksi Administratif dalam Hukum Lingkungan di Indonesia," J. Huk. Lingkung. Indones., vol. 6, no. 1, pp. 41-71, (2019). 